\title{
Comparison of Intercropped Sorghum- Soybean Compared to its Sole Cropping
}

\author{
Saberi AR* \\ Department of Agricultural \& Natural Resources, Research \& Education Centre of Golestan Province, Iran
}

Received: January 17, 2018; Published: January 29, 2018

*Corresponding author: Saberi AR, Agricultural \& Natural Resources Research \& Education Centre of Golestan Province, Gorgan, Iran; Email: alireza_sa70@yahoo.com

\begin{abstract}
In order to find the best planting pattern of soybean (Glycine max L. Merill) with sorghum (Sorghum bicolor L.) intercropping, this research performed in Gorgan and Aliabaad. Experiment compared on three levels inform of pure sorghum with density of 250000 plant per hectare, intercropping of sorghum and soybean with density of 250000 and 400000 plant per hectare, respectively and intercropping of sorghum and soybean with density of 300000 and 480000 plant per hectare, respectively. The number of planting lines was 60 liens with length of 66.66 meters and $50 \mathrm{~cm}$ interval. For measuring of plant height, number of tiller, stem diameter and number of node, 10 bushes randomly harvested by using quadrate. By the way total surface area based of project protocol also harvested. For the results analysis t-test applied. Fresh forage production at treatment of intercropping with 300000 and 480000 plant density for sorghum and soybean, respectively in Gorgan \%33.33 and in Aliabad \%34.32 had priority compared to check treatment (sole cropping of sorghum with density of 250000 plants per hectare). Mean comparison of dry forage also indicated \%24.01 increasing in Gorgan and \%26.12 in Aliabaad.
\end{abstract}

Keywords: Planting pattern; Yield component; Plant density; Morphological treats

Abbreviations: PH: Plant Height; NT: Number of Tiller; ST: Stem Diameter; NF: Number of Leaf; NN: Number of Node; LSR: Leaf to Stem Ratio; PE: Panicle Emergence; PT: Pollination Time; DH: Days to Harvesting

\section{Introduction}

\section{Overview}

With the increase in world population, demand for food consequently will grow. It is expected that human population will increase to over 8 billion by the year 2020 and this will worsen the current scenario of food security. Improved crop productivity over the past 50 years has resulted in increasing world food supplies up to $20 \%$ per person and reducing proportion of foodinsecure peoples living in developing countries from $57 \%$ to $27 \%$ of total population [1]. It is predicted that at least 10 million people will be hungry and malnourished in the world by the end of this century [1]. Thus, to reduce the food insecurity, crop production will have to be doubled, and produced in more environmentally sustainable ways [2]. This can be achieved by expanding the area of crop production, increasing per hectare yield and improving crop quality. Furthermore, during the second half of the past century, rise in per hectare crop productivity was due to improved or high yield potential [3]. In view of the current situation of food security, particularly in developing countries, a number of other factors have caused a further decrease in crop productivity. These important factors include land availability for agricultural activities, fresh water resources, biotic and abiotic stresses, and low economic activity in agricultural sector.

However, it is generally believed that land availability for agricultural considered to be the main source of the yield reduction $[4,5]$. The current trend in climatic changes also enhanced the frequency and intensity of water shortage in sub-tropical area of Asia and Africa [6]. This greatly contributes to the world problems in water resources, as a result, production of agricultural crops are adversely affected from the shortage of irrigation water. However with improvement in water and irrigation use efficiency, crops and their products provide $57 \%$ of the total value of production of agriculture, forestry and fisheries in developing countries. In Asia, this share amounts to 58\%, in sub-Saharan Africa, 53\%, in Latin America and the Caribbean, 51\% and in West Asia-North Africa $69 \%$.

Sorghum [Sorghum bicolor (L.) Moench] was domesticated in Ethiopia about 5000 years ago. Approximately 70\% (62 million tons) of the world's sorghum production and 89\% (45 million ha) of sorghum areas are located in the developing regions. Asia is a major region for this crop, with about 12 Mha or $28 \%$ of the global 
crop area. Sorghums are an important source of dietary energy to most of Asia. Productivity is low due to the low yield potential of existing cultivars and the biotic and abiotic constraints [7]. Sorghum ranks fifth among the world cereals, following wheat, maize, rice and barley in production area and was cultivated in Egypt as early as 2000 B.C. In a warm and long summer it can regrow during the same season after cutting. But yield is affected by growth conditions. Hence, producers should pay more attention in selecting the appropriate species to meet their need [8].

Warm season annual grasses provide substantial forage yield in a short period of time. However, when high temperatures and shortterm drought stress often limit growth during the summer months, forage sorghum fills the gap in providing relatively high quality forage [9]. A general assumption in intercropping cereals with legume crops is that the legume, when associated with the specific Rhizobium, may have most of its $\mathrm{N}$ need supplied through fixation of atmospheric $\mathrm{N}$, leaving the soil available $\mathrm{N}$ for the companion cereal. There is evidence that leguminous plants can benefit the intercrop cereals in the same season through $\mathrm{N}$ excretion and nodule decomposition $[10,11]$. There is marked variation in the $\mathrm{N}$ supplying ability among legume species [12].

Competition between component crops for growth-limiting factors is regulated by morph physiological differences and agronomic factors such as the proportion of crops in the mixture and fertilizer application $[13,14]$. Intraspecific competition seems to be more intense than intraspecific competition. It has been observed that the roots of intercrops freely intermingle resulting in complementary interactions between the root systems, such as $\mathrm{N}$ transfer or complementary use of different nutrients $[15,16]$. Studies on $\mathrm{N}$ transfer from forage legumes to grass have demonstrated that transfer occurs over a distance of at least $20 \mathrm{~cm}$, and reaches a maximum when the legume/grass ratio is greater than 1:1 [17]. The efficiency of cereal-legume intercrop systems, expressed as land equivalent ratio (LER), increases, remains unchanged or decreases under application of increasing levels of $\mathrm{N}$ fertilizer [18-22]. The relationship between legume and growth of forage sorghum under different planting pattern and plant density is not well understood. Many changes take place in plants to enable them to compete and maintain photosynthetic activity.

A consideration of the adaptation mechanisms by which density affects photosynthesis would aid the improvement of growth conditions and crop yield and would provide useful tools for future genetic engineering. Works in the late 1980s demonstrated that yields can be raised two to three-fold by using available improved varieties and appropriate agronomic techniques. But, these findings need to be refined, improved and tested for local climatic, soil and crop conditions. These include in the aspects of to what extent of planting pattern and plant density affect the yield and morpho-pysiological parameters of forage sorghums. In addition, no comprehensive database is available on forage sorghums under combination of pattern and density. Thus, studies are still needed to improve understanding of the effects of pattern and density for different forage crop (corn and sorghum).
As the $\mathrm{N}$ supply and plant population definition are basic parameters for cereal-legume intercropping, this study was conducted to examine the effects of bean plant population on dry matter production, yield and efficiency of maize-bean intercrop system and sorghum bean intercrop system. Effective strategies which include planting pattern management should be undertaken to overcome/mitigate the adverse effects of different plant density. Many factors need to be considered when addressing the suitability of planting arrangement with respect to plant density. However, only a deeper understanding of these events will enable the development of new cultivars capable of tolerating cultivation system and consequently, capable of supporting higher yields during stress situations. Other factors include rootstock or variety, manure lack, stage of plant growth and irrigation management. Hence, the present study was to design with the following objectives:

\section{Objectives}

To determine the performance of soybean and forage sorghum at different levels of plant density in sole cropping and intercropping patterns. To identify how planting pattern and plant density affect the fresh yield dry yield and morphological parameters of soybean and forage sorghum in sole and intercropping systems.

\section{Materials and Methods}

\section{Site Description}

a) Location: Gorgan and Ali Abad

b) Start Date: 3.5. 2015

Duration of the experiment: One year

The mean climatic conditions recorded were $30{ }^{\circ} \mathrm{C}$ temperature, $70 \%$ humidity and $4.5 \mathrm{~mm}$ evaporation. The temperature was measured using a thermometer (Extech® Model 407026).

\section{Layout of the Experiment}

The treatments were planting pattern factor included: pure culture of sorghum and one row soybean, one row sorghum, The other factor planting density included: optimum density (250000 sorghum plant +40000 legume plant) and $20 \%$ more than optimum plant density (300000 sorghum plant +480000 legume plant). Each plot was contain sixty lines. Planting rows were with length of 66.66 $\mathrm{m}$ and width of $50 \mathrm{~cm}$. The phenotypic data were collected from the middle rows. The traits under study in sorghum were included: plant height (ph), number of tiller (NT), stem diameter (ST), number of leaf (NF), number of node (NN), leaf to stem ratio (LSR), panicle emergence (PE), pollination time (PT), days to harvesting (DH). The trait studied in legume included: NN, number of sheath, number of sub-stem, number of grain in sheath, $\mathrm{PH}$, internodes length, SD, NL, flowering time, time to sheath emergence. For measuring of these parameters, 10 bushes randomly harvested by using quadrate. By the way total surface area based of project protocol also harvested. The selected field was under wheat cultivated, after harvesting wheat on 15 June of 2015. The considered land plowed in deep of $20-25 \mathrm{~cm}$, then with cross of desk made ready for planting. For the results analysis t-test applied. 


\section{Results and Discussion}

\section{Results}

Fresh forage production of sorghum-soybean at plant density of 250000 and 400000 plants ha $^{-1}$ respectively in Gorgan \% 63.4 and in Aliabad \% 37.5 had priority compare to sole cropping treatment of sorghum at plant density of 400000 plants ha-1. Mean comparison of dry matter yield also showed increased yield in Gorgan \% 58.9 and in Aliabad \% 43.07 .Fresh forage production of intercropping of sorghum-soybean at plant density of 250000 and 400000 plants ha $^{-1}$ respectively in Gorgan \% 41.12 and in Aliabad \% 28.91 had priority compare to sole cropping treatment of sorghum at plant density of 400000 plants ha-1. Mean comparison of dry matter yield also showed increased yield in Gorgan \% 44.61 and in Aliabad \% 43.07 (Table 2). Fresh forage production of intercropping of sorghum-soybean at plant density of 300000 and 480000 plants ha $^{-1}$ respectively in Gorgan \% 37.77 and in Aliabad \% 12.07 had

$$
\text { Table } 1 \text { Yield comparion of fresh forage and dry forageof soybean a }
$$

Table 1: Yield comparison of fresh forage and dry forage of soybean at intercropped sorghum- soybean compared to its sole cropping at high plant density.

\begin{tabular}{|c|c|c|c|c|c|}
\hline $\begin{array}{l}\text { Experiment } \\
\text { size }\end{array}$ & Treatment & $\begin{array}{c}\text { Yield of fresh } \\
\text { forage ton ha(1) }\end{array}$ & $\begin{array}{l}\text { Different percentage of } \\
\text { Recommended Treatment } \\
\text { compared to soya been }\end{array}$ & $\begin{array}{c}\text { Yield of dry forage } \\
\text { ton ha(1) }\end{array}$ & $\begin{array}{l}\text { Different percentage of } \\
\text { Recommended Treatment } \\
\text { compared to soya been }\end{array}$ \\
\hline \multirow{4}{*}{ Gorgan } & $\begin{array}{l}\text { Sole cropping of } \\
\text { sorghum with density } \\
\text { of } 250000 \text { plant ha }^{-1}\end{array}$ & 23.08 & - & 4.11 & - \\
\hline & $\begin{array}{c}\text { Intercropping of } \\
\text { sorghum and soybean } \\
\text { with plant density } \\
\text { of } 300000 \text { plant ha }{ }^{-1} \\
\text { and } 480000 \text { plant ha }{ }^{-1} \\
\text { respectively }\end{array}$ & 39.20 & 41.12 & 7.42 & 44.61 \\
\hline & Amount of calculated $t$ & $10.11^{*}$ & - & $5.45^{*}$ & - \\
\hline & Amount of table $t$ & 2.62 & - & 2.62 & - \\
\hline \multirow{4}{*}{ Ali abad } & $\begin{array}{l}\text { Sole cropping of } \\
\text { sorghum with density } \\
\text { of } 250000 \text { plant ha }{ }^{-1}\end{array}$ & 23.600 & - & 4.03 & - \\
\hline & $\begin{array}{l}\text { Intercropping of } \\
\text { sorghum and soybean } \\
\text { with plant density } \\
\text { of } 300000 \text { plant ha }{ }^{-1} \\
\text { and } 480000 \text { plant ha }{ }^{-1} \\
\text { respectively }\end{array}$ & 33.200 & 28.91 & 7.08 & 43.07 \\
\hline & Amount of calculated $t$ & $14.05^{*}$ & - & $20.97^{*}$ & - \\
\hline & Amount of table $t$ & 2.62 & - & 2.62 & - \\
\hline \multirow[b]{2}{*}{$\begin{array}{l}\text { Average of } \\
\text { two region }\end{array}$} & $\begin{array}{l}\text { Sole cropping of } \\
\text { sorghum with density } \\
\text { of } 250000 \text { plant ha }{ }^{-1}\end{array}$ & 23.34 & - & 4.07 & - \\
\hline & $\begin{array}{c}\text { Intercropping of } \\
\text { sorghum and soybean } \\
\text { with plant density } \\
\text { of } 300000 \text { plant ha }{ }^{-1} \\
\text { and } 480000 \text { plant ha }{ }^{-1} \\
\text { respectively }\end{array}$ & 36.20 & 35.01 & 7.25 & 43.84 \\
\hline
\end{tabular}

priority compare to intercropping treatment of sorghum-soybean at plant density of 250000 and 400000 plants ha $^{-1}$ respectively (Table 3).

Comparing two plant densities showed (Tables 1-3) better performance of high plant density. However this amount less than one LER lead to increase performance of intercrop. Mean comparison of dry yield showed the highest amount of dry forage obtained from 1 row soya +1 row sorghum treatment with 4.07 ton ha $^{-1}$ production. However sole cropping sorghum with 7.24 ton ha $^{-1}$ production (29.01 ton/ ha) had third ranking (had lowest amount of dry forage). As shown at (Table 4) interaction of planting pattern and plant density become significant at studied characters. In case of legume yield, the best combination treatment from pure soybean with \%20 higher density (31.2 ton per hectare) obtained. Considering flowering date and pudding bean at second and planting pattern was earlier than other treatments and compare to soybean sooner got flower and pod. 
Table 2: Yield comparison of fresh forage and dry forage of soybean at intercropped sorghum- soybean compared to its sole cropping at medium plant density.

\begin{tabular}{|c|c|c|c|c|c|}
\hline Experiment size & Treatment & $\begin{array}{c}\text { Yield of fresh forage } \\
\text { ton ha(1) }\end{array}$ & $\begin{array}{l}\text { Different percentage } \\
\text { of Recommended } \\
\text { Treatment compared } \\
\text { to soya been }\end{array}$ & $\begin{array}{c}\text { Yield of dry forage } \\
\text { ton ha(1) }\end{array}$ & $\begin{array}{l}\text { Different percentage } \\
\text { of Recommended } \\
\text { Treatment compared } \\
\text { to soya been }\end{array}$ \\
\hline \multirow{4}{*}{ Gorgan } & $\begin{array}{l}\text { Sole cropping of } \\
\text { sorghum with density } \\
\text { of } 250000 \text { plant ha }^{-1}\end{array}$ & 23.08 & - & 4.11 & - \\
\hline & $\begin{array}{l}\text { Intercropping of } \\
\text { sorghum and soybean } \\
\text { with plant density } \\
\text { of } 300000 \text { plant ha } a^{-1} \\
\text { and } 480000 \text { plant ha- }{ }^{-1} \\
\text { respectively }\end{array}$ & 39.20 & 41.12 & 7.42 & 44.61 \\
\hline & Amount of calculated $t$ & $10.11^{*}$ & - & $5.45^{*}$ & - \\
\hline & Amount of table $t$ & 2.62 & - & 2.62 & - \\
\hline \multirow{4}{*}{ Ali abad } & $\begin{array}{l}\text { Sole cropping of } \\
\text { sorghum with density } \\
\text { of } 250000 \text { plant ha }^{-1}\end{array}$ & 23.600 & - & 4.03 & - \\
\hline & $\begin{array}{l}\text { Intercropping of } \\
\text { sorghum and soybean } \\
\text { with plant density } \\
\text { of } 300000 \text { plant ha- }{ }^{-1} \\
\text { and } 480000 \text { plant ha- }{ }^{-1} \\
\text { respectively }\end{array}$ & 33.200 & 28.91 & 7.08 & 43.07 \\
\hline & Amount of calculated $t$ & $14.05^{*}$ & - & $20.97^{*}$ & - \\
\hline & Amount of table $t$ & 2.62 & - & 2.62 & - \\
\hline \multirow[b]{2}{*}{ Average of two region } & $\begin{array}{l}\text { Sole cropping of } \\
\text { sorghum with density } \\
\text { of } 250000 \text { plant ha }^{-1}\end{array}$ & 23.34 & - & 4.07 & - \\
\hline & $\begin{array}{l}\text { Intercropping of } \\
\text { sorghum and soybean } \\
\text { with plant density } \\
\text { of } 300000 \text { plant ha- }{ }^{-1} \\
\text { and } 480000 \text { plant ha- }{ }^{-1} \\
\text { respectively }\end{array}$ & 36.20 & 35.01 & 7.25 & 43.84 \\
\hline
\end{tabular}

Table 3: Yield comparison of fresh forage and dry forage at intercropped sorghum- soybean at high and medium plant density.

\begin{tabular}{|c|c|c|c|c|c|}
\hline $\begin{array}{l}\text { Experiment } \\
\text { size }\end{array}$ & Treatment & $\begin{array}{c}\text { Yield of fresh } \\
\text { forage ton } \\
\text { ha(1) }\end{array}$ & $\begin{array}{l}\text { Different percentage of } \\
\text { Recommended Treatment } \\
\text { compared to soya been }\end{array}$ & $\begin{array}{c}\text { Yield of dry } \\
\text { forage ton ha(1) }\end{array}$ & $\begin{array}{l}\text { Different percentage of } \\
\text { Recommended Treatment } \\
\text { compared to soya been }\end{array}$ \\
\hline \multirow{4}{*}{ Gorgan } & $\begin{array}{c}\text { Sole cropping of sorghum } \\
\text { with density of } 250000 \text { plant } \\
\text { ha }^{-1}\end{array}$ & 39.20 & - & 7.42 & - \\
\hline & $\begin{array}{l}\text { Intercropping of sorghum } \\
\text { and soybean with plant } \\
\text { density of } 300000 \text { plant } \\
\text { ha- } 1 \text { and } 480000 \text { plant ha }{ }^{-1} \\
\text { respectively }\end{array}$ & 63.00 & 37.77 & 710.01 & 25.8 \\
\hline & Amount of calculated $t$ & $5.21^{*}$ & - & $5.10^{*}$ & - \\
\hline & Amount of table $t$ & 2.62 & - & 2.62 & - \\
\hline \multirow[b]{2}{*}{ Ali abad } & $\begin{array}{l}\text { Sole cropping of sorghum } \\
\text { with density of } 250000 \text { plant } \\
\text { ha }^{-1}\end{array}$ & 33.20 & - & 7.08 & - \\
\hline & $\begin{array}{l}\text { Intercropping of sorghum } \\
\text { and soybean with plant } \\
\text { density of } 300000 \text { plant } \\
\text { ha }^{-1} \text { and } 480000 \text { plant ha }^{-1} \\
\text { respectively }\end{array}$ & 37.76 & 12.07 & 7.086 & 0.08 \\
\hline
\end{tabular}




\begin{tabular}{|c|c|c|c|c|c|}
\hline & Amount of calculated $t$ & $1.52^{*}$ & - & $0.014^{*}$ & - \\
\hline & Amount of table $t$ & 2.62 & - & 2.62 & - \\
\hline \multirow[b]{2}{*}{$\begin{array}{l}\text { Average of two } \\
\text { region }\end{array}$} & $\begin{array}{l}\text { Sole cropping of sorghum } \\
\text { with density of } 250000 \text { plant } \\
\text { ha }^{-1}\end{array}$ & 36.20 & - & 7.25 & - \\
\hline & $\begin{array}{l}\text { Intercropping of sorghum } \\
\text { and soybean with plant } \\
\text { density of } 300000 \text { plant } \\
\text { ha }^{-1} \text { and } 480000 \text { plant ha }^{-1} \\
\text { respectively }\end{array}$ & 51.38 & 24.92 & 10.44 & 12.94 \\
\hline
\end{tabular}

Table 4: Correlation coefficients between morphological parameters of legume.

\begin{tabular}{|c|c|c|c|c|c|c|c|c|c|c|c|}
\hline & $\begin{array}{c}\text { Sheathing } \\
\text { date }\end{array}$ & $\begin{array}{c}\text { Flowering } \\
\text { date }\end{array}$ & $\begin{array}{c}\text { Number } \\
\text { of leaf }\end{array}$ & $\begin{array}{c}\text { Stem } \\
\text { diameter }\end{array}$ & $\begin{array}{c}\text { Height } \\
\text { till first } \\
\text { done }\end{array}$ & $\begin{array}{c}\text { Inter } \\
\text { node } \\
\text { distance }\end{array}$ & $\begin{array}{l}\text { Plant } \\
\text { height }\end{array}$ & $\begin{array}{c}\text { Number } \\
\text { of seed at } \\
\text { sheath }\end{array}$ & $\begin{array}{c}\text { Number } \\
\text { sub of } \\
\text { stem }\end{array}$ & $\begin{array}{l}\text { Number } \\
\text { of shaeth }\end{array}$ & $\begin{array}{c}\text { Number } \\
\text { of node }\end{array}$ \\
\hline $\begin{array}{c}\text { Flowering } \\
\text { date }\end{array}$ & $0.998^{* *}$ & & & & & & & & & & \\
\hline $\begin{array}{c}\text { Number } \\
\text { of leaf }\end{array}$ & 0.043 & 0.042 & & & & & & & & & \\
\hline $\begin{array}{c}\text { Stem } \\
\text { diameter }\end{array}$ & $0.291^{* *}$ & $0.291^{* *}$ & $0.478^{* *}$ & & & & & & & & \\
\hline $\begin{array}{l}\text { Height till } \\
\text { first done }\end{array}$ & $0.140^{*}$ & $0.137^{*}$ & $0.137^{* *}$ & $0.741^{* *}$ & & & & & & & \\
\hline $\begin{array}{l}\text { Inter node } \\
\text { distance }\end{array}$ & $0.199^{* *}$ & $0.197^{* *}$ & $0.790^{* *}$ & $0.610^{* *}$ & $0.755^{* *}$ & & & & & & \\
\hline $\begin{array}{l}\text { Plant } \\
\text { height }\end{array}$ & $0.133^{*}$ & $0.131^{*}$ & $0.862^{* *}$ & $0.362^{* *}$ & $0.653^{* *}$ & $0.834^{* *}$ & & & & & \\
\hline $\begin{array}{l}\text { Number } \\
\text { of seed at } \\
\text { sheath }\end{array}$ & 0.039 & 0.038 & 0.044 & $0.684 * *$ & $0.474^{* *}$ & $0.187^{* *}$ & -0.101 & $0.563^{* *}$ & & & \\
\hline $\begin{array}{c}\text { Number } \\
\text { sub of } \\
\text { stem }\end{array}$ & $0.240^{* *}$ & $0.238^{* *}$ & $0.804^{* *}$ & $0.634^{* *}$ & $0.768^{* *}$ & $0.801^{* *}$ & $0.736^{* *}$ & $0.600^{* *}$ & $0.300^{* *}$ & & \\
\hline $\begin{array}{l}\text { Number } \\
\text { of shaeth }\end{array}$ & $0.152^{*}$ & $0.150^{*}$ & $0.701^{* *}$ & $0.717 * *$ & $0.790^{* *}$ & $0.658^{* *}$ & $0.614^{* *}$ & $0.631^{* *}$ & $0.510^{* *}$ & $0.795^{* *}$ & \\
\hline $\begin{array}{l}\text { Number } \\
\text { of node }\end{array}$ & $0.133^{*}$ & $0.138^{*}$ & $0.267^{* *}$ & $0.367 * *$ & $0.211^{* *}$ & $0.273^{* *}$ & $0.167^{*}$ & $0.170^{*}$ & $0.196^{* *}$ & $0.242^{* *}$ & $0.253^{* *}$ \\
\hline
\end{tabular}

** , * and ns are significant at 0.01, 0.05 level and non significant, respectively

\section{Discussion}

Investigation of total fresh forage showed that Intercropping of sorghum and soybean with plant density of 300000 plant ha- 1 and 480000 plant $^{-1} \mathrm{a}^{-1}$ respectively was better treatment and 24.92 percent had more production compared to check treatment [23-26], from study of density and different planting ratio at intercropping of sorghum and soya got below results: with increasing density the yield of sorghum and soybean at intercropped system increased and 1 row sorghum with 1 row soybean was better than sole cropped treatment. From this investigation resulted that increasing plant density caused to flowering and pudding be faster. For example from comparing different levels of density at I6D2 pattern, the highest number of leaf (17.9) on plant obtained. Changing density couldn't create significant different on plant height on the same planting pattern. Other point, plant height of soybean is lowest than sorghum, because of stolen growth of soy bean. But considering number of pod at soybean plant is better than sorghum. In view of LER, at none of the legume treatment this treat doesn't become more than one. Therefore intercropping of legume compare to pure cultivation has been less performance. Study of interaction of planting pattern and plant density sorghum at all studied treat except number of tillers were significant.

\section{Final Result}

LER of 1 row sorghum+1 row soybean was better than other treatment, Therefore this treatment as best recommended treatment more than one, elaborated LER. This treatment $60 \%$ was better than pure cultivate and if each crop alone was sown for getting this yield the area needed was equal to 1.6. This subject had shown the better performance of intercropping compare to pure cultivation. That confirms other results. However highest fresh forage yield from pure soybean with high plant density obtained and the production was $31200 \mathrm{~kg} \mathrm{ha}^{-1}$, the yield of 1 row sorghum +2 rows soybean with yield of $30392 \mathrm{~kg} \mathrm{ha}^{-1}$ had second ranking.

\section{References}

1. FAO (2003) Fertilizer use by crop in Uzbekistan. FAO, Rome. 
2. Borlaug NE, Dowswell CR (2005) Feeding a world of ten billion people: a $21^{\text {st }}$ century challenge. In: Tuberosa T, Phillips RL, Gale M (Eds.) Proceeding of In the Wake of Double Helix: From the Green Revolution to the Gene Revaluation. 2003, at Bologna, Italy. Avenue Media, Bologna, Italy, pp. 3-24.

3. Arous JL, Slafer GA, Reynolds MP, Royo C (2004) Physiology of yield and adaptation in wheat and barley breeding. In: Blum A, Nguyen H (Eds.). physiology and biotechnology integration for plant breeding Marcel Dekker. New York, USA, pp. 1-49.

4. Rehman S, Harris PJ, Ashraf M (2005) Stress environments and their impact on crop production. In: Ashraf M, Harris (Eds.). Breeding and Molecular Approaches. Haworth Press, New York, USA, pp. 3-18.

5. Reynolds M, Tuberosa R (2008) Translatial research empacting on crop productivity in drout-prone environments. Current Opinion in Plant Biology 11: 117-179.

6. Kerrn K (2007) Global warming and landslides. Centre for Bioenvironmental Research. Tulane University and Xaver University. Urban Society and Ecology. Katrina Environmental Research and Restoration Network (KERRN).

7. ICRISAT (International Crops Research Institute for Semi Arid Tropics) (2009) Annual report. Patancheru, Andhra Pradesh, India.

8. Qureshi AS, Qadir M, Heydari N, Turral H, Javadi A (2007) A review of management strategies for salt-prone land and water resources in Iran. International water management Institute. 30P (IWMI working paper 125) Colombo, Sri Lanka.

9. Teutsch C (2006) Warm-season annual grasses for summer forage. Communication and Marketing, College of Agriculture and Life Sciences, Virginia Polytechnic Institute and State University.

10. Saito SMT (1982) The nitrogen relationships of maize/bean associations. In Graham PH, Harris SC (Eds.). Biological nitrogen fixation. Cali: Centro Internacional de Agricultura Tropical pp. 631-639.

11. Bonetti R (1991) Transferência de nitrogênio do feijão para o milho consorciado: avaliação pelo método de diluição isotópica do $15 \mathrm{~N}$ e efeito da associação micorrízica. 63 f. Tese (Doutorado em Agronomia) - Escola Superior de Agricultura Luiz de Queiroz, Piracicaba.

12. Senaratne R, Liyanage NDL, Soper RJ (1995) Nitrogen fixation and N transfer from cowpea, mungbean and groundnut when intercropped with maize. Fertilizer Research Dordrecht 40: 41-48.

13. Trenbath BR (1976) Plant interaction in mixed crop communities. In: PAPENDICK RI, SANCHES PA, TRIPLETT GB (Eds.), multiple cropping. Madison: American Society of Agronomy p. 129-169.
14. Russell JT, Caldwell RM (1989) Effect of component densities and nitrogen fertilization on efficiency and yield of maize/soyabean intercrop. Experimental Agriculture Cambridge, England, 25: 529-540.

15. Natarajan M, Willey RW (1980) Sorghum-pigeonpea intercropping and the effects of plant population density - 2: resource use. Journal of Agricultural Science Cambridge, England, 95: 59-65.

16. Adiku SGK, Ozier-Lafontaine H, Bajazet T (2001) Patterns of root growth and water uptake of a maize-cowpea mixture grown under greenhouse conditions. Plant and Soil Dordrecht 235: 85-94.

17. Brophy LS, Heichel GH, Russelle MP (1987) Nitrogen transfer from forage legumes to grass in a systematic design. Crop Science Madison 27: 753-758.

18. Searle PGE, Comudom S, Shedden DC, Nance RA (1981) Effect of maize, legume intercropping systems and fertilizer nitrogen on crop yields and residual nitrogen. Field Crops Research Amsterdam 4: 133-145.

19. Baker CM, Blamey FPC (1985) Nitrogen fertilizer effects on yield and nitrogen uptake of sorghum and soybean, grown in sole cropping and intercropping systems. Field Crops Research Amsterdam 12: 233-240.

20. Ofori F, Stern WR (1986) Maize/cowpea intercrop system: effect of nitrogen fertilizer on productivity and efficiency. Field Crops Research Amsterdam 14: 247-261.

21. Pilbeam CJ, Wood M, Mugane PG (1995) Nitrogen use in maize-grain legume cropping systems in semi-arid Kenya. Biology and Fertility of Soils Berlin 20: 57-62.

22. Siame J, Willey RW, Morse S (1998) The response of maize Phaseolus intercropping to applied nitrogen on Oxisol in northern Zambia. Field Crops Research Amsterdam, 55: 73-81.

23. Beheshti AR, Kocheki A (1997) Effects of different plant density and sowing rate on yield and yield components of intercropped grain sorghum and soybean. Thesis of Agronomy. Ferdosi University, Mashhad, Iran. (In Persian, with English Abstract.)

24. Ofori F, Stern WR (1987) The combined effects of nitrogen fertilizer and density of the legume component on production efficiency in a maize/ cowpea intercrop system. Field Crops Research, Amsterdam 16: 43-52.

25. Oljaca S, Cvetkovic R, Kovacevic D, Vasic G, Momirovic N (2000) Effect of plant arrangement and irrigation on efficiency of maize (Zea mays) and bean (Phaseolus vulgaris) intercropping system. Journal of Agricultural Science Cambridge, England, 135: 261-270.

26. SAS Institute (2004) SAS/STAT user's guide. release. Release 9.0. 4th ed. Statistical Analysis Institute, Cary, NC.
This work is licensed under Creative Commons Attribution 4.0 License

Submission Link: http://biomedres.us/submit-manuscript.php

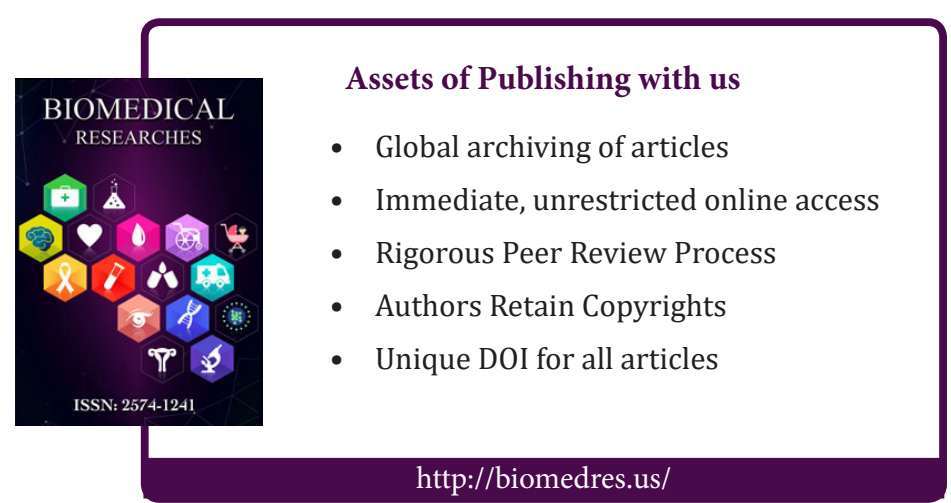

